\title{
Influence of nest structure and age of the bee queen on preparation of protein feed by bees
}

\author{
Mishchenko O. ${ }^{1}$, Lytvynenko O. ${ }^{2}$, Afara K. ${ }^{3}$, Kryvoruchko D. ${ }^{4}$ \\ ${ }^{1-3}$ NSC «Institute of beekeeping named after P.I. Prokopovich» \\ ${ }^{4}$ National University of Life and Environmental Sciences of Ukraine \\ e-mail: ${ }^{1 h}$ oney72@i.ua, 2alesyasandra@ukr.net, ${ }^{4}$ dimokmpx@ukr.net \\ ORCID: ${ }^{2}$ 0000-0001-6643-2285, ${ }^{4} 0000-0003-1788-6090$
}

\begin{abstract}
Goal. To study the influence of the structure of the bee family nest and the age of the bee queen on the flight-collecting activity of bees during the preparation of protein feed. Methods. Laboratory, zootechnical (strength of the bee family) and statistical (mathematical processing). Results. The position on the relationship between the entry of pollination into the bee family and the different age of the brood and the age of the bee queen is substantiated. The age of the bee queen, open brood and indicators of bee pollination activity are directly related: the younger the bee queen and the greater the number of open brood, the higher the harvesting activity, the more bee pollen is collected. Conclusions. Increased collection of bee pollen is provided by the use of queen bees in bee colonies for no more than two bee-keeping seasons. Timely change of queen bees, as well as building and maintaining the strength of bee colonies are the main zootechnical measures to maintain optimal life of bees and get the maximum amount of products from them. Bee queens should not be changed or replaced during honey collection or harvesting. It is better to replace the queen bees before the main honey harvest so that the bee colony already has a fertile bee queen before it starts. Taking into account the dynamics of the use of bees in the harvesting bee pollen, the replacement of queen bees should be carried out only in view of the reserves of protein feed (perga) in the nests of bee colonies and specific terrain with plants that provide bees with pollen.
\end{abstract}

Key words: honey bees, Ukrainian steppe breed, bee pollination, pollen, brood, collecting activity of bees. DOI: https://doi.org/10.31073/agrovisnyk202010-04

The vital activity of the honey bees family, particularly brood raising, successful wintering, resistance to diseases, flight-collecting and pollinating activity depends significantly on the supplies in the nest and the flow of the protein food - bee pollen [1, 2]. For the pollen collection bees have specific anatomical characteristic of the legs structure: pollen brush, auricle, pollen baskets on the hind legs, pollen brush and spur on the middle legs, on the forelegs there's antennae cleaner that helps to remove pollen from antennae. The tibia of the hind legs holds the recess and the row of the long hairs curved to the mid forming pollen basket used by bees to collect pollen in the form of granules called bee pollen. The inner side of the first segment of the hind legs has 9-10 firm hairs located transversally forming pollen brush used by bees to remove the pollen from the body [3, 4].

Bee pollen, or flower pollen is the complex concentrated vegetative bee product with unique consuming and curative qualities. It is the combination of pollen grains, or male microgamethophytes of seed plants that were collected and treated with nectar and the salivary glands secretion $[5,6]$.

The activity of the bee pollen collection is determined by the number of factors which influence the collection of the protein food. Among them are climatic and floristic conditions as well as the immediate need of the bee families for the protein food [7]. The collecting activity of bees depends on the number of factors, in particular, temperature, light intensity, wind, rain, and is directly related to all these factors. With insufficient number or lack of protein food the bee family reduces or stops the process of raising the brood and producing of wax, reduces the power and honey productivity, and at the time of wintering there is high mortality rate and death of bee families causing heavy economic losses $[8,9]$.

The presence of the queen bee in honey bees family fully affects their flight activity while collecting the bee pollen. In its absence all the activities connected to harvesting of the bee pollen and its processing as well as producing of wax, and comb building, brood raising, collecting of nectar, slow down significantly and later stop entirely. With the presence of the queen bee the functioning of the family as an integrated system recovers [10]. The reduction of the intensity of the activities or their full suspension is the important biological adaptive reaction of the bee families that allows to maintain the power and the capacity of the bees to raise a large amount of brood [11, 12].

The species composition and the mass of the bee pollen collected by bees are influenced by many factors and primarily by the quantity and diversity of plant pollen in nature, while its formation to a lesser extent depends on natural and climatic conditions than nectar productivity of plants [13, 14].

The first question arose in selecting and use of the queen bees concerns the optimal terms of their use. Some believe that queen bees in the bee families should be replaced every year, while others propose to do that for the second or even the third year. We should also bear in mind that depending on the natural conditions, particularly on the duration of the active period as well as the power of the bee family, the intensity of egglaying, species characteristic, periods of their effective use will be unequal. If the active vitality period of bees is short, if the family is not strong and the queen bee throughout the year lays approximately $75-100$ thousands of eggs, its physiological ageing will come later. On the contrary, with prolonged period the queen bee in the 
strong families can lay 150-200 thousands of eggs per season In that case the body of the queen bees gets worn out much more quickly and physiological ageing happens sooner.

The objective of this research was to study the influence of the bee nest structure and the age of the queen bee on the flight and collective activity of bees in harvesting of the protein food which in turn, will allow to determine the optimal age of the queen bee replacement in the bee families.

Materials and methods of research. The study was conducted on the basis of experimental apiary of the National Scientic Centre "Beekeeping institute named after P.I. Prokopovich". As the research subject the honeybees of the Ukrainian steppe breed, combs, bee bread and bee pollen were chosen were chosen

The tasks of the study were solved with the help of zootechnical (the power of the bee family) and statistical (mathematical treatment) methods of research.

To perform the task, we formed three groups of the bee families of the Ukrainian steppe breed, three families in a group. Families were selected on the principle of analogues. Bee families conformed the standards of the Ukrainian steppe bee confirmed by the results of the evaluation of the exterior. In the selection of the pairs the power of the bee family, the age of the queen bee, the hive construction, the quantity of the food were taken into account. The selection of the bee pollen was conducted using pollen catcher. The development of the brood was also controlled.

Families were kept in the long hives measuring $435 \times 300 \mathrm{~mm}$. Caring for the bee families of both groups was conducted in the same way, according to the generally accepted methodology.

The hives of the bee families of the research groups were equipped with pollen catchers with lattice with 178 openings, $4,9 \mathrm{~mm}$ in diameter each. Pollen catchers were switched on throughout the conduction of the whole research.- three days switched on/three days switched off. The accounting of the flight activity in collecting the pollen was performed in each of the three groups at the time of strengthened activity of bees from 9 to 12 a.m. The accounting of the growth of the bee families and the storage of the pollen was conducted every 12 days throughout May - June, taking into account the quantity of the sealed brood and the quantity of the bee bread quadrants.

Accounting the number of bees of the experimental and control groups, which brought the bee pollen, was performed for 30 minutes and the weight of the bee pollen was determined in the process. The weight of the bee pollen was determined on torsion scale VT-500.

Results. Changing the structure of the nest, we conducted the control accounting of the flight activity of the bees in collecting the bee pollen. The graph shows that the flight activity was not high (picture 1, curve K).

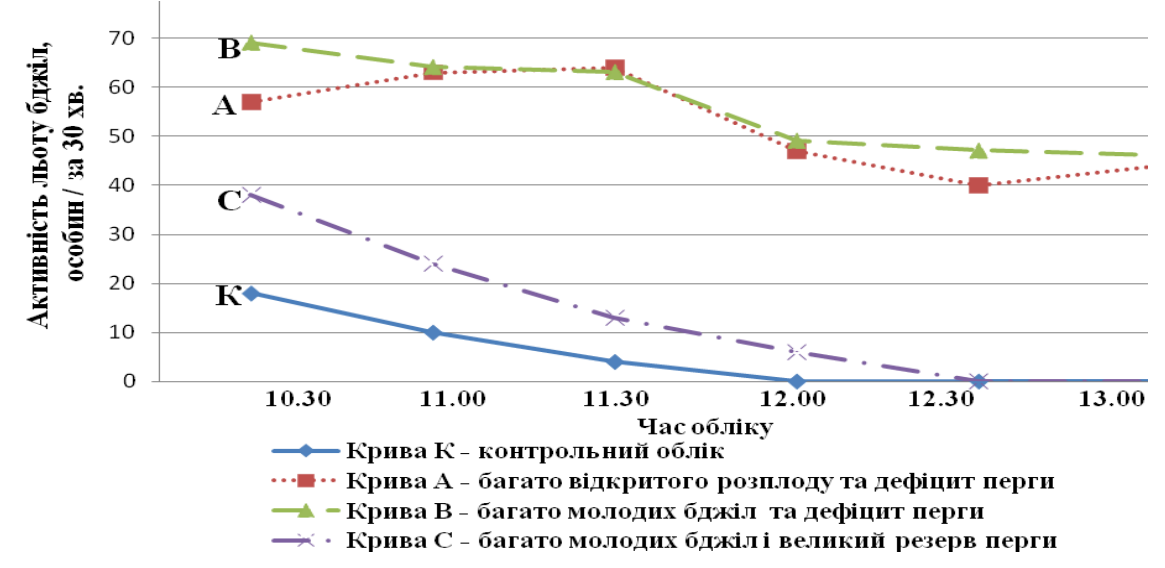

The flight activity of bees in collecting of the bee pollen

Furthermore, as planned, we added to the experimental bee families combs with open brood (sowing of the larvae 1-4 days old in a number approximately 2500 combs), taken from another family. In two days (after the adaptive period) the bee pollen collecting activity changed significantly comparing to control groups. The next day the results were similar. On the graph the average results of the collecting activity are submitted (picture 1, curve A).

After the completion of the research with the open brood, the latest was returned to the maternal family and was replaced with the combs with the brood «on the exit» In two days the experimental families were filled with young bees. The collecting activity was high comparing to the control group (picture. 1, curve B). At the same day after the completion of the research, the combs with the open brood were removed and replaced with the comps with the bee bread, meaning instead of the deficit of the protein food, its reserve was created. The first accounting already indicated the decrease of the flight activity comparing to the previous version of the research. Furthermore the flight activity kept gradually decreasing and in 2,5 hours it stopped fully, while in previous variations of the study within the same interval of time it remained sufficiently high. The research was conducted with three frequencies and the results were similar. The average results are displayed on the (picture 1, curve C). After the completing the research the combs with bee bread were removed, but the number of the young bees in families remained the same and their need of the protein food was high. The further accounting showed that the flight activity of bee pollen collectors was high, similar to the one displayed on the graph (picture 1, curve B). 
It should be pointed out that the bee pollen collecting activity of the bees with the large amount of the open brood and young bees (variations $A$ and $B$ ) exceeds ten times the rates of the control group. When demand in protein food is high, coupled with its excessive amounts, the flight activity decreases (variatin C). Therefore, different factors that specify the flight and collecting activity were studied.

As for the age of the queen bee and collecting activity of the bees, the research has shown that the age of the queen bee and the rates of bee pollen collecting activity are directly related: the younger the queen bee, the higher the collecting activity, the more bee pollen is collected fr the family (table 1).

\section{The age of the queen bee and collecting activity of the bees}

\begin{tabular}{|c|c|c|c|c|}
\hline \multirow{3}{*}{ Rate } & \multirow{3}{*}{$\begin{array}{c}\text { The age } \\
\text { f the } \\
\text { queen } \\
\text { bee, } \\
\text { years } \\
\end{array}$} & \multicolumn{3}{|c|}{ Monthsi } \\
\hline & & May & June & July \\
\hline & & $M \pm m$ & $M \pm m$ & $M \pm m$ \\
\hline \multirow{3}{*}{ Open brood, hundreds of combs } & 1 & $67 \pm 5,61$ & $94 \pm 7,88$ & $73 \pm 6,07$ \\
\hline & 2 & $68 \pm 5,61$ & $120 \pm 10,05$ & $112 \pm 9,31$ \\
\hline & 3 & $38 \pm 3,17$ & $80 \pm 6,67$ & $49 \pm 4,13$ \\
\hline \multirow{3}{*}{ Bee bread, quadrants } & 1 & $27 \pm 3,33$ & $35 \pm 4,32$ & $42 \pm 5,18$ \\
\hline & 2 & $23 \pm 2,85$ & $55 \pm 6,78$ & $53 \pm 6,55$ \\
\hline & 3 & $20 \pm 2,47$ & $27 \pm 3,32$ & $21 \pm 2,48$ \\
\hline \multirow{3}{*}{$\begin{array}{l}\text { Bees arrived, in } 5 \text { minutes, unit, } \\
\text { overall / including the ones with bee } \\
\text { pollen }\end{array}$} & 1 & $\begin{array}{c}110 \pm 0,51 \\
44 \pm 0,20\end{array}$ & $\begin{array}{c}138 \pm 0,65 \\
71 \pm 0,32\end{array}$ & $\begin{array}{c}176 \pm 0,83 \\
87 \pm 0,40\end{array}$ \\
\hline & 2 & $\begin{array}{c}126 \pm 0,58 \\
35 \pm 0,15\end{array}$ & $\begin{array}{l}245 \pm 1,14 \\
120 \pm 0,56\end{array}$ & $\begin{array}{l}258 \pm 1,19 \\
133 \pm 0,62\end{array}$ \\
\hline & 3 & $\begin{array}{l}88 \pm 0,41 \\
27 \pm 0,12\end{array}$ & $\begin{array}{l}95 \pm 0,44 \\
52 \pm 0,25\end{array}$ & $\begin{array}{c}145 \pm 0,68 \\
75 \pm 0,35\end{array}$ \\
\hline
\end{tabular}

Thus, on average, the collecting activity of the bees-collectors in the group of families with three years old queen bees is lower on $23,4 \%$ comparing to the groups with one year old queen bees and is less on $46,9 \%$ comparing to the groups with two year old queen bees.

The accounting of the productivity of queen bees of different age (table 2) has shown that the families with one year old queen bees collected on the average $2408 \pm 140 \mathrm{~g}$ (or 27,5\%) of the bee pollen more than the families with the two years old queen bees, the two year old bees collected on the average $2928 \pm 156 \mathrm{~g}$ (or $55,1 \%$ ) more than families with three year old bees.

\section{The productivity of bees with the queen bees of the different age}

\begin{tabular}{|c|c|c|c|c|}
\hline \multirow[b]{2}{*}{ The age of the queen bee } & \multicolumn{3}{|c|}{ Product collection of the bee pollen, $g$} & \multirow{2}{*}{$\begin{array}{c}\text { Duration of } \\
\text { work of the } \\
\text { pollen catche } \\
\text {, days. }\end{array}$} \\
\hline & $\mathrm{M} \pm \mathrm{m}$ & Lim & td & \\
\hline 1 year & $2408 \pm 140$ & $1240-2825$ & $-1,54$ & \multirow{3}{*}{70} \\
\hline 2 years & $2928 \pm 156$ & $1396-5100$ & $-3,26$ & \\
\hline 3 years & $1888 \pm 121$ & $914-2744$ & - & \\
\hline
\end{tabular}

\section{Conclusions}

The studies provide standing to claim that the increase of the collecting of bee pollen is provided by the use of the queen bees not older than two beekeeping seasons. Families with the one year old queen bees collected the bee pollen by $27,5 \%$ more than the ones with the two year old queen bees, the ones with the two year old queen bees collected bee pollen by 55,1\% more than the ones with the three year old queen bees.

The timely replacement of the queen bees every two years, as well as increasing and preserving the power of the bee families are the main zootechnical methods for maintaining the optimal level of their vital functions and obtaining the maximum amount of bee products.

In the experimental conditions it was determined that the highest flight activity of bees while collecting the bee pollen was displayed in the presence of the fertile queen bee and the large numbers of young bees and open brood. Therefore, given the dynamics of the use of bees during the harvesting of the bee pollen, the replacement of the queen bees should be done only taking into account the stock of the protein feeds (bee bread) in the nests of the bee families and specific conditions of the area with honey plants that provide bees with pollen. 


\section{References}

1. Brodschneider, R., \& Crailsheim, K. (2010). Nutrition and health in honey bees. Apidologie, 41(3), 278294. doi: $10.1051 / a p i d o / 2010012$

2. Campana, B. J., \& Moeller, F. E. (1977). Honey bees: Preference for and nutritive value of pollen from five plant sources. Journal of Economic Entomology, 70(1), 39-41. doi: 10.1093/jee/70.1.39

3. Omar, E., Abd-Ella, A. A., Khodairy, M. and other. (2017). Influence of different pollen diets on the development of hypopharyngeal glands and size of acid gland sacs in caged honey bees (Apis mellifera). Apidologie, 48(4), 425-436. doi: 10.1007/s13592-016-0487-x

4. Corby-Harris Vanessa, Snyder Lucy, Meador Charlotte. (2019). Fat body lipolysis connects poor nutrition to hypopharyngeal gland degradation in Apis mellifera. Journal of Insect Physiology, 116, 1-9. doi: 10.1016/j.jinsphys.2019.04.001

5. Nicolson, S. W. (2011). Bee food: The chemistry and nutritional value of nectar, pollen and mixtures of the two: Review article. African Zoology, 46(2), 197-204. doi: 10.3377/004.046.0201

6. Liolios, V., Tananaki, C., Dimou, M., and other. (2015). Ranking pollen from bee plants according to their protein contribution to honey bees. Journal of Apicultural Research, 54, 582-592. doi: 10.1080/00218839.2016.1173353

7. Crailsheim, K., Schneider, L., Hrassnigg, N., Bühlmann, G. and other. (1992). Pollen consumption and utilization in worker honey bees (Apis mellifera carnica): Dependence on individual age and function. Journal of Insect Physiology, 38(6), 409-419. doi: 10.1016/0022-1910(92)90117-V

8. Schmickl, T., Crailsheim, K. (2002). How honeybees (Apis mellifera L.) change their broodcare behaviour in response to non-foraging conditions and poor pollen conditions. Behav Ecol Sociobiol , 51, 415-425. doi: 10.1007/s00265-002-0457-3

9. Horn, Juliane \& Becher, Matthias \& Kennedy and other (2015). Multiple stressors: Using the honeybee model BEEHAVE to explore how spatial and temporal forage stress affects colony resilience. Oikos, 12 doi: 10.1111/oik.02636

10. Elina, L. Niño, Osnat, Malka, Abraham, Hefetz, and other. (2012). Effects of honey bee (Apis mellifera L.) queen insemination volume on worker behavior and physiology. Journal of Insect Physiology, 58(8), 10821089, doi: 10.1016/j.jinsphys.2012.04.015

11. Walsh, Elizabeth \& Rangel, Juliana. (2016) Local Honey Bee Queen Production and Quality, Bee World, 93(2), 30-32, doi: 10.1080/0005772X.2016.1211501

12. Rangel, J., Keller, J. J., \& Tarpy, D. R. (2013).The effects of honey bee (Apis mellifera L.) queen reproductive potential on colony growth. Insectes Sociaux, 60,65-73. doi: 10.1007/s00040-012-0267-1

13. Radev, Z. (2018).Variety in protein content of pollen from 50 plants from Bulgaria. Bee World, 95(3), 8183. doi: 10.1080/0005772X.2018.1486276

14. Urcan, A., Marghitas, L., Dezmirean, D. S., and other. (2017). Chemical composition and biological activities of beebread - Review. Bulletin of University of Agricultural Sciences and Veterinary Medicine Cluj-Napoca. Animal Science and Biotechnologies, 74, 6-14. doi: 10.15835/buasvmcn-asb:12646 